
8
Research Square
Preprints are preliminary reports that have not undergone peer review.
They should not be considered conclusive, used to inform clinical practice, or referenced by the media as validated information.

\title{
Correlation-and-regression Analysis of the Influence of Macroeconomic Factors on Capital Structure of Russian Corporations Under Crisis Conditions
}

\section{Valeria Valeryevna Metelskaya ( $\sim$ lerametelskaya@mail.ru )}

\section{Research}

Keywords: leverage, capital structure, trade-off theory, pecking order theory, stock market development, macroeconomic factors

Posted Date: December 18th, 2020

DOI: https://doi.org/10.21203/rs.3.rs-27181/v2

License: (c) (i) This work is licensed under a Creative Commons Attribution 4.0 International License. Read Full License

Version of Record: A version of this preprint was published at Journal of Innovation and Entrepreneurship on July 8th, 2021. See the published version at https://doi.org/10.1186/s13731-021-00160-w. 


\section{Abstract}

The study reveals the influence of macroeconomic factors on decisions about the optimal capital structure formation under financial globalization, in view of ever-changing factors of the external economic and geopolitical environment. The study is aimed at empirical testing of hypotheses on how the level of financial leverage of corporations depends on traditional determinants during and after the financial crisis under the emerging market conditions in Russia. The study deals with a large data set of 49 public joint stock companies from 7 leading Russian economic sectors for the period from 2011 to 2017. According to the correlation-and-regression analysis results, (1) the use of traditional theories of capital structure under the conditions of current financial globalization in a country with a developing economy proves to be ineffective for the optimal capital structure formation (2) the corporate capital structure formation is strongly influenced by macroeconomic factors, which is most evidently manifested during and after the crisis, (3) the financial crisis exerts a strong influence on the corporate capital structure, (4) the determinant of stock market development has a significant influence on leverage and plays a prominent role in making financial decisions after the financial crisis.

JEL classification: E22, E44, F6, F15

\section{Introduction}

Under financial globalization, in view of ever-changing factors of the external economic and geopolitical environment, the modern economy dictates new rules of conduct at all levels, which results in the revision of conventional financial theories. The growing contradictions in economic, political and social spheres in the course of development and intensification of the financialization process provoke new economic downturns and financial crises. As a result, the decisions on the choice of corporate financing should be based not solely on traditional approaches to the capital structure formation, but also on the exact reasons and key macroeconomic factors that influence the capital structure.

There are several theories of capital structure that explain the preferences and conduct of companies depending on the choice of corporate financing. The main scientific theories of capital structure are as follows: trade-off theory and pecking order theory. The authors of the first theory, that emerged during the discussion of the Modigliani-Miller theorem (1963), claim that in the formation of equity and debt capital the balance shall be achieved between the tax shield benefits, that ensure tax saving in the case of raising loans, and bankruptcy risks resulting from excessive debt burden (Kraus and Litzenberger, 1973; Jensen and Meckling, 1976; Myers, 1977; Bradley et al., 1984; Jensen, 1986; Morellec, 2004, Koksal et al., 2013; Kuhnhausen and Stieber, 2014; Duan, Chik bin. And Liu, 2012; Matemilola et al., 2012; Adair and Adaskou, 2015; Serrasquero and Caetano, 2015). Thus, the trade-off theory suggests that a company exchanges its benefits and costs for the debt and equity financing and finds an optimal capital structure, considering the tax benefits, bankruptcy and agency costs. The second theory, which is based on the information asymmetry between investors of the corporation and its managers, deals with the distribution of financing sources in a hierarchical order from the least to the most attractive for the 
company, provided that internal sources are more preferable than external ones, while among external sources, debt is more preferable than the issuance of shares. Therefore, it is postulated that decisions on the capital structure are made at the expense of an unpromising choice between the firm and external investors. (Donaldson, 1981; Myers and Majluf, 1984; Myers, 1984; Beattie, Goodacre, Thomson, 2006; Camara, 2012; Dincergok and Yalciner, 2011; Barros and Silveira, 2008; Hackbarth, 2009; Park and Kim, 2009; Fedyk, 2014; Rihab and Lotfi, 2016).

These theories help to understand the corporate capital structure, as well as to reveal potential internal and external factors; however, they do not consider various company-specific factors, which in turn lead to contradictory forecasts and ambiguous results under conditions of financial crises. Many researchers try to elucidate the relationship between capital structure and its determinants, substantiating the reasons and regular patterns of occurrence and influence of various internal and external factors, which can have impact on the choice of corporate financing (Raian and Zingales, 1995; Booth et al., 2001; Deesomsak et al., 2004; Antoniou et al., 2008; Sbeiti, 2010; Fan et al., 2012; Belkhir et al., 2016). Furthermore, the identification of general reasons and macroeconomic consequences for capital structure in the conditions of a highly volatile financial market and, consequently, periodic financial crises, appears to be a little-investigated issue. In several existing studies on the specified issues the authors reach a consensus for the first time that economic downturns exert a significant influence on the company's financial behavior (Duchin et al., 2010; Judge and Korzhenitskaya, 2012; Iqbal and Kume, 2013; Akbar et al, 2013; Harrison and Widjaja, 2014).

The present study, which is based on the existing scientific descriptions and explanations of the factors that determine the choice of an optimal capital structure, as well as on earlier hypotheses and assumptions, contributes to the analysis of this important scientific issue. To date, there is an obvious lack of theoretical and mainly applied results of empirical research in this area, especially for domestic companies. In the domestic literature, the main attention is paid to the development of ideas on the procedure for choosing sources of financing and options for the theory of behavioral financial structures (Lisitsa M.I., 2002, Blank I.A., 2017; Bocharov V.V., 2009; Stoyanova E.S., 2010; Volkov, Nikulin, 2012), the study of the choice of the capital structure as a stage of strategic planning (Gubanov O.V., 2007). This study tries for the first time, by means of correlation-and-regression analysis, to identify any regular patterns of a financial crisis in the conditions when the forecasts arising from traditional theories of capital structure may fall short of expectations. Besides, the results of such analysis can be immediately put into practice by Russian corporations.

On the whole, the results of this study may be interesting for several reasons.

Firstly, the Russian economy is an ideal environment to explore how determinants affect the corporate capital structure during the crisis, because the Russian economy is developing and therefore it is substantially affected by various macroeconomic factors and significantly dependent on the development of the global financial market and global corporate capital. Secondly, based on the findings it will be possible to identify, whether the effects of such determinants increase or decrease before, during 
and after the crisis. The comprehension of such complex relationships is crucial for analysis and neutralization of unfavorable consequences of the financial crisis when making decisions on the corporate capital structure formation. Thirdly, the issues on the optimal capital structure formation become highly relevant in the context of the global financial crisis, which made many companies and even entire industries struggle for survival. It is worth noting that that this issue is practically not covered in studies. Most studies (Deloof, 2003; Etjuly, 2004; Dong, Su, 2010; Volkov, Nikulin, 2012) were based on data samples, not including crisis periods. However, it is deemed that the following main problem will be solved with the formation of companies' financial management policy: what influence does the financial crisis exert on the leverage of companies in order to ensure their effective performance.

This study was aimed at the empirical testing of hypotheses on how the level of corporate financial leverage depends on traditional determinants, based on the multiple-regression model with panel data. Based on this study it is possible to reveal the influence of a financial crisis on the relationship between company-specific factors, macroeconomic factors, determinants of stock market development and corporate capital structure. In view of the dynamic relationship between leverage and its determinants, a target adjustment model is used in the study, which admits the deviation of companies from their optimal leverage so as to perform another adjustment in the course of time. GMM (generalized method of moments) is used to evaluate the dynamic model. This study uses a large data set from 49 companies, whose securities are admitted to the stock exchange trading, from 7 Russian economic sectors for the period from 2011 to 2017. The separation of data among industries will reveal significant differences between economic sectors depending on their future prospects.

The article has the following structure. The second part presents a summary review of the literature about the influence of external and internal factors on leverage within the framework of the main capital structure theories. The third part deals with the planning of study methodology and selection of variables. The fourth part presents the empirical finding of the study, including correlation-and-regression analysis between variables. Finally, the last part summarizes and evaluates the findings.

\section{Theoretical Justification}

Studies on the capital structure are based on two main competing theories, which try to explain the reasons for using leverage. Trade-off theory considers a combination of factors that collectively determine an optimal capital structure. Through constant maintenance of the company's assets and investment plans, the company optimizes its debt ratio, with account of the trade-off between costs and benefits of borrowing (debt financing) (DeAngelo and Masulis, 1980; Myers, 1984). The theory is based on the tax advantages of debt (income tax shield), which are balanced with financial costs arising from bankruptcy (Myers, 2003).

According to the authors of the second theory, it is necessary to choose a particular means for company's capital mobilization, based on the hierarchy of preferences ("pecking order"), according to which sources of financing are distributed in a hierarchical order from the least to the most attractive for the company, 
provided that internal sources are more preferable than external ones, while among external sources, debt is more preferable than the issuance of shares (Donaldson, 1981). According to the concept of asymmetric information (Myers, Majluf, 1984), if insiders are better informed about the company's affairs than external investors, it is most likely that the company's shares will be underestimated by the market. As a result, financing of investment projects through the issuance of shares may turn out to be so expensive for the company that winning over new investors (and simultaneously losing old ones) may exceed the project's net present value (NPV) due to the underestimation of shares. For this reason, the issuance of shares is considered to be the least attractive source of financing. On the contrary, internal sources of financing are not affected by information asymmetry and should be used in the first place for the financing of company projects. The pecking order theorists suggest that one of the reasons why company's managers choose internal financing as a priority is their subjective motivations to follow the path of least resistance, evading the stock market discipline, as well as a relief from the costs related to the issuance of new securities (Brealey and Myers, 2003).

Thereafter, the hypothesis about the impact of information asymmetry on the choice of financing source was transformed into a signaling theory, according to which not objective, but subjective factors determine the choice of capital structure due to the unequal availability of information about the market situation for market participants (Brigham and Erhardt, 2008). It is assumed that managers tend to maximize the value of shares owned by current shareholders at any given moment, rather than prospective shareholders. Therefore, if a firm has good prospects, its managers will not undertake the issuance of new shares, preferring debt financing, but in the case of poor prospects it will be more profitable for current shareholders to finance at the expense of the issuance of new shares. As a result, the issuance of new shares will be regarded by investors as an alarm signal, and the share prices usually drop after the announcement of a new issuance.

The literature, devoted to the capital structure theories, gives a detailed representation of factors that influence the decision-making process and corporate financing methods, namely: company growth potential, share of the company's tangible assets, profitability, company size, risk, liquidity, as well as macroeconomic conditions such as inflation, GDP growth and indicators of the stock market development (Jensen and Meckling, 1976; Titman, Wessels, 1988; Myers and Majluf, 1984; Frank and Goyal, 2008; Titman and Wessels, 1988; Rajan and Zingales, 1995; Frank and Goyal, 2009; Fama and French, 2002; Warner, 1977; Ang et al., 1982; Titman and Wessels, 1988; Chkir and Cosset, 2001; Bevan, Danbolt, 2002; Harris and Raviv, 1991; Bancel and Mittoo, 2004; Brierley and Bunn, 2005; Koksal et al., 2013; Kuhnhausen and Stieber, 2014; Sett and Sarkhel, 2010; Hanousek and Shamshur, 2011; Chen, 2003; Hall, Hutchinson, Michaelas, 2004; Cassar, Holmes, 2003; Esperanca, Pantzalis, 2003; Bastos, Nakamura and Basso, 2009; Bokpin, 2009; Dincergok and Yalciner, 2011; Camara, 2012). The article considers the above-listed factors in terms of an econometric model that describes the influence of a financial crisis on the corporate capital structure. Thus, it is reasonable to detect the specific characteristics of their correlation with leverage from the perspective of two traditional theories of capital structure.

\subsection{Trade-off theory}


According to the trade-off theory, company growth potential is negatively correlated with leverage, because companies with better future prospects, as a rule, face greater financial difficulties and agency costs between shareholders and bondholders due to the risk shifting (Jensen and Meckling, 1976; Titman, Wessels, 1988) or underinvestment (Myers, 1977). Consequently, companies tend to underuse the debt financing when building an optimal capital structure. The hypothesis about the sources of financing at different life-cycle stages of a company was made by Mel Scot and Richard Bruce (1987), who believe that at the initial development stage a company arranges financing with its own resources until a steady cash flow is generated from operating activities. During the adolescence-stage a company can already use bank loans as debt financing. The development of credit history takes place during this period, with a focus on further increase of the amount of available financing, extension of loan terms, and lowering of rates. At the next growth stage, a company can use bonded loans, which will attract additional financial resources, as well as will help the company in improving its internal processes and establishing cooperation with the investment-banking community. Further development of a company is characterized by the opportunity to use the advantages of foreign capital markets for long-term fund raising through the issuance of various corporate securities.

According to the trade-off theory, the company's tangible assets have an extremely controversial influence on leverage: companies with large tangible assets may have a higher leverage due to lower agency costs and less financial difficulties, which is expressed by a positive correlation between materiality and leverage (Titman and Wessels, 1988; Rajan and Zingales, 1995; Frank and Goyal, 2009). However, the disciplinary role of debt becomes less important in companies with large tangible assets, which implies a negative correlation between materiality and debt (Grossman and Hart, 1982; Titman and Wessels, 1988).

The trade-off theory suggests that profitability has a positive impact on leverage, because profitable companies with large cash holdings usually use debt financing to ensure the optimal use of free cash flow (Fama and French, 2002). This is explained by low bankruptcy risks, tax saving and low agency costs.

The company size is directly correlated with leverage, because large companies, as opposed to small and medium-sized enterprises, usually have a low probability of default and, thus, low financial costs, which makes it possible for large companies to maintain high leverage ratio. (Warner, 1977; Ang et al., 1982; Titman and Wessels, 1988; Chkir and Cosset, 2001; Bevan, Danbolt, 2002). In confirmation of the above statement, Marsh (1982), Bennett and Donnelly (1993), making a study on how company size influences capital structure, revealed that large companies have a quite significant amount of debt obligations. Consequently, following this logic, company size must have a positive correlation with leverage.

Supporters of the trade-off theory think that risk has a negative impact on capital structure. This is conditioned by the fact that companies with higher income volatility carry higher bankruptcy risks (Harris and Raviv, 1991; Bancel and Mittoo, 2004; Brierley and Bunn, 2005; Frank and Goyal, 2009). According to some researchers, the companies' liquidity ratio is inversely proportional to financial leverage, which means that companies with high liquidity tend to use less debt (Singhania, Seth, 2010). 
Macroeconomic factors (particularly, inflation and GDP growth) can also have a significant impact on the company's leverage ratio. Another important macroeconomic factor that influences the corporate structure is capital market development. Thus, inflation has a profound positive impact on capital structure, because high inflation reduces the real value of debt, prompting companies to take on more debts (Frank and Goyal, 2009; Koksal et al., 2013; Kuhnhausen and Stieber, 2014; Sett and Sarkhel, 2010; Hanousek and Shamshur, 2011). The researchers believe that GDP growth has an ambiguous influence on capital structure. Countries with high GDP growth rates have better opportunities for company growth (which has a negative impact on leverage), but at the same time they are more profitable (which has a positive impact on leverage). For example, Gajurel (2006) holds that there is a negative correlation with total debt ratio and short-term debt ratio, but this has a positive impact on long-term debt ratio. Finally, the stock market development may influence the capital structure. According to the trade-off theory of capital structure, the influence of stock market development is ambiguous. According to Bokpin, these variables are not correlated (Bokpin, 2009). However, Sett and Sarkhel (2010) show that there is a negative correlation between capital structure and stock market development. Moreover, according to Duan, Chik bin. and Liu (2012), financial market index has negative correlation with debt ratio. Companies choose long-term loans in the case of higher percentage of non-state economy and greater development of a financial sector.

\subsection{Pecking order theory}

Firstly, the pecking order theory postulates that there is a positive correlation between growth potential and leverage, arguing that additional resources are required for company growth in order to finance future investments (Myers and Majluf, 1984; Frank and Goyal, 2008). Some researchers believe that the company's future growth prospects have a positive correlation with debt obligations, especially with short-term ones (Chen, 2003; Hall, Hutchinson, Michaelas, 2004). Moreover, agency problems and the resulting costs of financing may decrease if a company issues short-term rather than long-term obligations. Thus, company growth should lead to the upswing of demand for additional sources of financing, which in turn will necessitate the use of debt financing sources.

Secondly, materiality has a negative impact on capital structure, because companies with a high ratio of tangible assets, as a rule, have less information asymmetry that reduces the capital value (Frank and Goyal, 2008). In general, it might be expected that tangible assets would have less information asymmetry than intangible assets. However, this might not happen - therefore, it is impossible to make an accurate forecast whether information asymmetry will always be lower, thus assuming an inverse correlation between materiality and leverage.

Thirdly, the pecking order theory supposes that profitability has a negative impact on leverage. This is conditioned by the fact that high profit is generated by a larger amount of internal resources for project financing and, consequently, with a lesser demand for debt financing (Myers and Majluf, 1984). Profitable firms with a certain level of profit can rely primarily on this profit, rather than on such external financing sources as credit, while companies with low profit margin are more dependent on credit resources due to 
the lack of own funds (Gaud, Hoesli, Jani, Bender, 2005). To confirm this standpoint, Cassar and Holmes (2003) put forward an assumption that profitability has a negative impact on the short-term and longterm obligations, and therefore there must be a negative correlation between profitability and leverage.

Fourthly, the pecking order theorists believe that company size has a negative impact on capital structure, because large companies, as a rule, experience less information asymmetry, reducing the capital value (Fama and Jensen, 1983; Rajan and Zingales, 1995). As a result, companies will issue more shares for the financing of their long-term capital requirements. But as for small and medium-sized enterprises, there is empirical confirmation of negative correlation between company size and short-term borrowing, but a positive correlation between company size and long-term borrowing (Cassar, Holmes, 2003; Esperanca, Pantzalis, 2003; Hall, Hutchinson, Michaelas, 2004).

Fifthly, risk is positively correlated with leverage, because companies with volatile income suffer more from an ill-chosen source of financing (Frank and Goyal, 2009).

Sixthly, according to the pecking order theory, liquidity has a negative impact on the company's capital structure. More liquid companies may use internal resources as a potential tool for capital mobilization, and therefore they will depend on debt financing to a lesser extent.

It is important to note the following macroeconomic factors that have a significant impact on leverage in terms of the pecking order theory. Inflation rate is negatively correlated with overall leverage and the short-term debt ratio, but it has a positive impact on the long-term debt ratio (Gajurel, 2006). However, empirical findings are different: according to Bastos, Nakamura, and Basso (2009), inflation does not influence capital structure; according to Frank and Goyal (2009), inflation is correlated with market leverage, but it does not influence leverage. Camara (2012) argues that macroeconomic conditions, including inflation rate, have a significant correlation with capital structure. Some authors believe that there is a profound negative correlation between capital structure and GDP, as well as GDP growth (Bastos, Nakamura and Basso, 2009; Bokpin, 2009; Dincergok and Yalciner, 2011; Camara, 2012). As for correlation between stock market development and leverage, some researchers believe that stock market development is positively correlated with capital structure (Dincergok and Yalciner, 2011). Moreover, market capitalization as indicator of stock market development has a positive impact on capital structure (Gajurel, 2006).

Within the framework of each mentioned theory of capital structure, the specified factors are presented in the table 1.

\section{Data Selection And Research Methodology}

This study is based on data from 49 corporations belonging to 7 leading Russian industries for the period from 2011 to 2017: oil and gas industry (OIGA), fuel and energy complex (FEC), chemical industry (CHEMIC), agro-industrial complex (AGRO), telecommunications industry (TELE), metallurgical industry (METALL), transportation services (TRANS) (table 2). The information on companies is collected from the 
Moscow Exchange Database and the server that discloses information published by issuers on the websites of authorized news agencies Interfax, AK\&M. The main selection criteria for companies were as follows: listing of companies' securities for trading and availability of financial reports subject to mandatory disclosure for a period of at least five years. Analysis does not include banks, lending agencies and financial companies, because their capital structure is incomparable with non-financial corporations.

Financial leverage ratio is usually chosen as a dependent variable of the multiple regression analysis of the company's capital structure. In this study, the ratio of total debt to total assets (TDTA) is defined as financial leverage:

\section{TDTA $=\frac{\text { ShortTerm Debt }+ \text { LongTerm Debt }}{\text { Total Assets }}$}

As independent variables of the model were chosen factors most frequently encountered in studies devoted to the current subject matter, and namely: company growth potential, share of the company's tangible assets, profitability, company size, risk, liquidity. As macroeconomic factors were used annual GDP growth and inflation rate, as well as market capitalization as indicator of stock market development.

Growth potential is calculated as annual growth of the company's total assets (Gross Total Assets).

Materiality is evaluated as net fixed assets divided by total assets (NFATA).

ROA (Return on Total Assets) calculated as the ratio of EBIT (Earnings before Interest and Taxes) to TA (Total Assets) is used as a proxy variable of profitability.

The company size is presented as net fixed assets index.

Liquidity is calculated as the ratio of current assets to current liabilities (CL).

Financial risk (FR) is used in this study as an indicator of company's risk, demonstrating which share of company's assets is being financed through the applied capital (equity capital and long-term liabilities).

Macroeconomic independent variables of this study are used as indicators of the dynamics of Russian stock market capitalization (SMC) to GDP, as well as indicators of annual GDP growth (GDPG), inflation rate (INFL).

The panel data set was processed with Microsoft Excel Office Suite, and the multiple regression models were developed with the software package Statistica.

Descriptive statistical samples of this study are presented in the tables 3-5, based on the periods before and after the crisis, as well as depending on economic sectors. A quick analysis of the tables shows clear signs of the imminent onset of the 2014 crisis and the impending recession of the Russian economy. In 2014, the Russian economy faced a serious monetary and financial crisis that escalated into a deep 
economic crisis. The sharp weakening of the Russian ruble against foreign currencies caused by the rapid decline in world oil prices, as well as the introduction of economic sanctions against Russia, led to many adverse consequences, in particular, an increase in inflation, a decrease in consumer demand, and an economic downturn. These factors could not but affect the activities of corporations in the leading sectors of the Russian economy.

Table 3 contains the mean values of these maximum, minimum values, as well as the average values of each variable for individual periods (pre-crisis, post-crisis and general periods). The analysis of data given in table 3 demonstrates that in more than half of the cases the average value of indicators is close to median. This indicates a relatively uniform sampling, which consequently demonstrates general trends in the capital structure formation of companies from various branches. The overall average value of the dependent variable TDTA (Total Debt to Total Assets) is $1.73 \%$. According to table 3 , the crisis has a minimal impact on financial leverage, as this ratio was $1.73 \%$ before the crisis and $1.62 \%$ after the crisis. However, a close statistical analysis of the sample standard deviation shows that the variance of leverage ratio between companies became slightly larger after the financial crisis $(1.10 \%)$, than before the crisis $(0.57 \%)$. But at the same time, the difference between maximum and minimum leverage values increased after the crisis, which can indicate that in the conditions of persistently high-volatile Russian economy, companies quickly recover from crisis shocks and experience a temporary revival and a certain degree of stabilization. Thus, although overall average values show a slight impact of the 2014 crisis on leverage ratios, such results may entail significant deviations, reduced through the averaging, which implies a further more extended and detailed check of the study samples depending on the period and individually for each economic sector. In spite of this deviation, quite interesting findings are presented in table 3. Thus, after the crisis, growth potential insignificantly improved (from $0.20 \%$ to $0.09 \%$ ), materiality slightly deteriorated (from $0.72 \%$ to $0.69 \%$ ); liquidity increased from $2.86 \%$ to $3.88 \%$, and net fixed assets index increased from $0.77 \%$ to $0.99 \%$; financial risk $(0.79 \%)$, as well as profitability remained at the same level. Although some of these changes forecast a lessening demand for debts, others lead to opposite effects. Thus, the influence of a crisis on financial leverage will depend on the predominance of particular factors. According to table 3 , changes in macroeconomic factors are deemed to be significant and are manifested through low value of average GDP growth $(0.96 \%)$ with a relatively high standard deviation (2.66\%). It may be concluded that Russia in view of its raw-material oriented economy and the lack of solid investments under economic sanctions cannot maintain a high GDP growth rate. Although this indicator shifted towards improvement before the crisis (3\%), the average GDP growth became negative $(-1 \%)$ in the post-crisis period. This is confirmed by adverse consequences of the financial crisis for the Russian economy. Low GDP growth was followed by high average inflation $(7.33 \%)$ and low but relatively stable values of market capitalization (37\% before the crisis and $39 \%$ after the crisis). Thus, Russian corporations in the leading economic sectors may be characterized as unattractive for foreign investors, underestimated by the market with missed investment opportunities and unrealized development potential during the whole study period.

Table 3 shows descriptive statistics of the study samples for independent and dependent variables, arranged by years (mean values). Although some variables underwent considerable changes during the 
crisis in 2014, the average leverage value did not change significantly even during this period. Crucial changes affected primarily macroeconomic indicators: dynamics of Russian stock market capitalization to GDP deteriorated significantly in 2014 and was $29 \%$, which is $21 \%$ less than in 2011 ; although GDP growth rate was low in 2011, it deteriorated since 2014 and even became negative; a surge of inflation was observed in 2014 (from $6.10 \%$ in 2011 to 11.36 \% in 2014), and by 2017 inflation dropped sharply to $2.52 \%$. The company growth potential in 2014 was also negative; profitability and materiality worsened. The net fixed assets index as of 2011 amounted to $0.76 \%$; however, its value became extremely unsatisfactory in 2014 (1.09\%). This means that during the crisis companies did not follow the general rule of long-term investment generation, primarily at the expense of the most reliable sources of financing, that is, at the expense of equity capital. Based on the analyzed data in table 4, it is possible to make an assumption about the influence of the financial crisis primarily on macroeconomic indicators and the overwhelming majority of analyzed variables.

Table 4 reflects the consequences of the financial crisis in 2014 on domestic corporations in the leading economic sectors. The overview of indicators shows that there are different trends depending on economic sector, but at the same time it is possible to detect some common patterns of the influence of the financial crisis on the development and functioning of public companies in most branches. Firstly, growth potential of the companies belonging to the fuel and energy complex (FEC) considerably worsened from $0.31 \%$ to $-0.15 \%$ and materiality deteriorated from $0.52 \%$ to $0.43 \%$, while leverage ratio increased sharply after the crisis from $0.66 \%$ to $1.35 \%$. This may be explained by the fact that in spite of poor investment prospects caused by low growth potential, companies of this branch have high operating costs that require financing through various forms of government support, in order to do away with insufficient internal resources. Russian companies in the chemical industry (CHEMIC) demonstrated a slight decrease in growth potential from $0.51 \%$ to $0.21 \%$, and decrease in profitability from $0.15 \%$ to $0.13 \%$. The same situation is observed in the metallurgical industry (METALL). However, as opposed to the chemical industry, the average financial leverage in the metallurgical industry surged dramatically from 2.31 to 4.07 . On the contrary, the average leverage of the transportation companies (TRANS) significantly decreased from 3.69 to -0.11 . This may mean that after the crisis, transportation companies became more profitable. The key drivers of the Russian economy - the oil and gas industry (OIGA) suffered slightly during the crisis. The average leverage remained almost unchanged after the crisis. Minor changes were observed in the average values of growth potential, materiality, ROA, net fixed assets index, liquidity and financial risk. However, Russian companies in the agro-industrial complex (AGRO) experienced extreme consequences due to the financial crisis: the averaged liquidity ratio increased significantly from $4.59 \%$ to $7.6 \%$, while the leverage ratio decreased from $1.61 \%$ to $0.85 \%$. Average liquidity of companies in the telecommunications industry (TELE) also increased sharply from $1.97 \%$ to $5.2 \%$, while ROA increased from $-0,02 \%$ to $0.07 \%$. This may be evidence of the increase in solvency of companies from the specified industries; however, a sharp increase in liquidity can also predict the formation of an irrational capital structure, which implies the insufficiently effective use of negotiable assets or short-term financing. Moreover, the agro-industrial and telecommunications industries display more caution in the use of leverages after the financial crisis. 
Table 5 also allows us to draw conclusions about the role of traditional determinants in each sector of the economy. For example, ROA dynamics became positive in the fuel and energy complex and the telecommunications industry after the $\mathbf{2 0 1 4}$ crisis, as well as significantly improved liquidity in these industries. In addition, after the crisis in the agro-industrial sector, the difference in the liquidity indicator was 3 points. This may mean that in conditions of financial uncertainty and high volatility of the financial market, the Russian economy, using the example of the main catalysts of the domestic economy - the fuel and energy complex and the innovative information industry, began to rely less on foreign capital due to the greater dependence on the mobilization of domestic savings for investment purposes. This means that under the current restrictions and sanctions, the Russian economy acquires hidden benefits from the high volatility of both the process of financial globalization itself and from its consequences - the financial crisis (V.V. Metel'skaya, 2018).

\section{Empirical Findings}

Pearson's correlation analysis was carried out as the first step of this study, which helped to detect the most interconnected indicators, to estimate trends of the analyzed correlations, as well as to determine the observations, the elimination of which from the population of analysis leads to significant changes in the ratio of estimated correlations. The findings differ depending on the study periods (general period from 2011 to 2017; pre-crisis period from 2011 to 2013 and post-crisis period from 2015 to 2017). Based on the matrix of paired correlation coefficients (Table 6), no strong dependences of macroeconomic indicators were revealed for the general period.

In the post-crisis period, the most significant indicators of correlation are macroeconomic factors, which show a strong correlation with each other, in particular, the GDP growth rate has a significant positive correlation with SMC (0.81), while inflation has a strong opposite impact on SMC (-0.93) and the GDP growth (-0.53). It may be noted that before the crisis in 2014, the company size significantly influenced its growth potential, as well as the company's choice of assets that are financed through the applied capital (equity capital and long-term liabilities). As opposed to the entire period, macroeconomic factors were distinguished by strong and different mutual influence.

According to the observations made since 2014, inflation has a strong negative impact on the GDP growth (-0.98) against the background of an obviously weakening correlation between the GDP growth, inflation and the dynamics of Russian stock market to GDP ( 0.50 and -0.65 , respectively).

The findings show the importance of the capital structure formation in the conditions of a financial crisis and other external unfavorable effects for the national economy. The findings also indicate a certain importance of the national economy's development insofar as it represents an emerging financial market with capability for rapid adaptation to external shocks or without such a property. Macroeconomic factors, determining the capital structure, play a prominent role in the making of financial decisions, particularly during the period when the functioning of the Russian stock market is actually restricted due to the financial crisis of 2014 and the imposition of sanctions. Proceeding from the correlation matrix, it 
may also be concluded that after the crisis, methods and strategies of the optimal capital structure formation were significantly revaluated by many companies, which resulted in the dramatic change of the nature of impact of financial risk on profitability (from -0.15 to 0.15 ), which suggests some caution when making a choice concerning the potential loss of financial resources and debt financing. Moreover, the financial crisis made an impact on the companies' ability to settle their obligations fully and within the time limit, depending on their overall performance and competitive capacity. If during the pre-crisis period, a steady decline of the companies' current solvency (CL) was observed under the competitive growth (Return on Assets), after the crisis this ratio changed and lost significant value. Thus, the analysis let us identify the priority areas of financial management within the specified time period. A company has a low liquidity in the case of positive dynamics of profitability indicators, which makes it necessary to take managerial decisions aimed at the balancing of these indicators. In view of the post-crisis situation, the issues connected with the achievement of an optimal level of liquidity and profitability ceased to be the financial management priorities.

As the second step of this study, the regression analysis was performed to define the correlation ratio between variables by constructing a matrix of multiple correlation coefficients (table 6), according to which throughout the entire study period, there is a statistical dependence between variables, and the indicators of the correlation ratio according to the Chedoke scale are predominantly high (0.7-0.9) and very high (0.9-0.99).

In particular, a strong close relationship is observed between FR and NFATA indicators (0.99) in the general period (2011-2017); ROA and IPA (0.99) in the pre-crisis period (2011-2013), FR and GTA (0.99) in the post-crisis period (2015-2017). The strong correlation between these variables means the following. The higher the risk of the company's activities, the greater the increase in net assets, which testifies to the increase in own funds in the process of carrying out financial and economic activities during the entire study period. A similar process can be traced in the post-crisis period. Thus, when the financial risk increases, companies have better growth opportunities. At the same time, in the pre-crisis period, the growth rate of profitability significantly influenced the increase in company size. These facts may be due to the following. Most companies consider the main negative consequences of the crisis to be a decrease in demand and an increase in production costs, which, in turn, put pressure on profitability. In addition, the lack of funding for new projects is cited as one of the most serious problems. This circumstance, given its negative impact on profitability, as well as the short-term orientation of a large number of shareholders, may have an extremely negative impact on the long-term growth opportunities of companies. At the same time, some companies, especially manufacturers of consumer goods operating in Russia, note the positive impact of devaluation on their prices relative to those companies that have a large share of imports in their purchases. In addition, the acceleration of inflation could threaten with a decrease in the parameters of the indexation of tariffs for electricity and gas for the population and industrial consumers. This could have a negative impact on the prospects for energy and gas companies, but for most sectors of the economy it could mean additional cost reductions, which are so necessary in a crisis. Thus, under the current circumstances, despite the growing financial risk, most companies did not lose their growth prospects and increase their assets. 
The regression models developed under such conditions are of high practical importance. The study gives an estimation of 4 variants of the model: the first variant includes only specific indicators for public companies, which usually influence the capital structure decisions (growth potential, materiality, profitability, company size, liquidity and financial risk); the second variant, along with the companyspecific characteristics, includes also main macroeconomic factors (GDP growth and inflation), in order to determine the influence of the general economic environment on leverage ratios; the third model makes an emphasis on the application of borrowed funds, debt in the conditions of supervision over the stock market development; the fourth variant covers all listed variables. All 4 models are constructed under 3 scenarios: from 2011 to 2017, from 2011 to 2013 and from 2015 to 2017, which correspond to the periods before and after the financial crisis of 2014 and the entire study period.

Let us proceeded to a more detailed analysis of the findings with regard to the hypothesis on the influence of a financial crisis on the capital structure formation.

\subsection{Results for the full period}

As shown in tables 7-10, for the period from 2011 to 2017 growth potential and profitability were the most important factors that influence leverage, and their characteristics correspond more to the trade-off theory, because company's growth potential has a negative impact on leverage, while profitability has a positive impact on it. Materiality, GDP growth and stock market development exert a little influence, which seems quite understandable, because the corporate capital structure is mainly determined by growth potential, profit margins and solvency. Financial risk, company size, liquidity are also insignificant variables, including in all four models for the analyzed period. However, materiality is positively correlated with leverage, while the variables of liquidity, financial risk and company size (for large companies, which are deemed to be the foundation of this analysis) have negative correlation, which corresponds to the trade-off theory. Low influence of these variables on leverage may be explained by the supply elasticity, where the choice of an optimal capital structure depends on easy access to credit resources for public companies, which are basically monopolists in their branches, but it does not imply effective capital mobilization by raising outside funds (external investment). For this reason, there is a poor correlation between stock market development and leverage, which is also negative in accordance with the trade-off theory.

From the analysis of models 1-4 for the period 2011-2017, the coefficient of determination (R2) shows how the conditional variance of the model differs from the variance of the real values of Y. Since R2 exceeds 0.5 and tends to 1 , the conditional variance of the model is quite small and very likely that the model describes the data well.

In almost each of the 4 proposed model scenarios, the regression model explains $74 \%$ of the fluctuations in the dependent variable in the sample. This level is high enough for a model describing financial and economic processes, especially in a transitional economy.

\subsection{Results for the pre-crisis period}

Page 14/39 
From the analysis of the first model for the period from 2011 to 2013 it follows that the most significant variables are materiality, profitability and company size (table 7). The share of company's tangible assets, as well as profitability are positively correlated with leverage. Liquidity has a negative and insignificant influence on leverage in all 4 models. Thus, the determinants of company's solvency before the financial crisis are more associated with the character of corporate assets and long-term savings, than short-term profit fluctuations.

Models 2 and 4 (tables 8 and 10) show a strong negative influence of company's financial risk on leverage. Moreover, the financial leverage ratio is very high and negative. This significant reduction of financial leverage may be conditioned by the fact that public companies used more debt capital before the crisis, which in turn forced creditors to increase lending rate, considering that an additional risk premium was built into it. At the same time, return on equity decreased, because some part of the profit generated by equity capital went for the repayment of high loan interest rates.

Macroeconomic variables (inflation and GDP growth) are significantly correlated with leverage during the pre-crisis period, which is consistent with the complete sample results for the entire period (model No. 2 according to table 8). Besides, during the pre-crisis period there was a strong positive influence of inflation on leverage. Such high inflation during the pre-crisis period can be explained by high collective consumption and relative certainty of loan offer. The GDP growth in the complete sample (table 10) is negatively connected with financial leverage, however, the model No. 3 (table 9) shows that the impact of GDP growth and dynamics of stock market capitalization on leverage is insignificant. But in accordance with model No. 4 (table 10), the stock market development in the complete sample is already significant and exerts a stable positive influence on leverage. Thus, this confirms the pecking order theory, according to which the stock market development is beneficial for debt liabilities, as well as for equity capital, because stock markets collect information on the issuing companies for banks and investors and, consequently, make the external financing less risky.

It may be concluded that during the pre-crisis period, the capital structure decisions were more dependent on macroeconomic factors, and predominantly on specific internal factors that determined the demand for debts.

\subsection{Results for the post-crisis period}

After the financial crisis of 2014, all models demonstrated that company growth potential does not have a significant influence on leverage, because the annual growth of company's total assets was not recorded both before and after the crisis, which is not consistent with the pecking order theory. In view of low profitability in the post-crisis period, the only alternative for companies is to borrow funds from creditors for the support of their business, rather than for the financing of their growth.

Profitability is still the most significant variable, but in the post-crisis period the positive influence on leverage significantly increased, as compared with the pre-crisis period (tables $7,8,9$ ). This correlation is inconsistent with the pecking order theory, suggesting that in the post-crisis period profitable companies 
with a certain level of profit cannot rely primarily and solely on this profit, and that they accumulate debt liabilities.

The company size in the pre-crisis period was more significant, as compared with the post-crisis period. Moreover, the materiality coefficient before 2014 was positive, in spite of some statistical insignificance demonstrated in some models. This indicator generally decreased in the post-crisis period and even exerted a significant negative influence on leverage in the complete sample according to table 10 (model No.4). Consequently, after the economic slowdown, large companies in the leading economic sectors were confronted with difficulties in raising funds from banks due to the absence of proven solvency. Moreover, precisely big companies with a large share of tangible assets fall into the group, against which economic and financial restrictions (sanctions) were imposed during the crisis. This is consistent with the pecking order theory.

The same as in the pre-crisis period, the variable of financial risk is still negative and has a significant influence on leverage. This is conditioned by the fact that since 2014 companies with higher income volatility carry higher bankruptcy risks.

Macroeconomic factors in the post-crisis period are as significant as in the pre-crisis period and have a prominent impact on the capital structure formation. But as opposed to the negative impact of GDP growth in the pre-crisis period, an obvious growth and a strong positive correlation between GDP growth and financial leverage were observed since 2014 (model No. 4 according to table 10). According to the trade-off theory and the pecking order theory, large growth leads to adverse effects that can be mutually compensated, which eventually will exert an insignificant influence on leverage. Based on this analysis, in accordance with main theories of capital structure the specified position is not confirmed.

The influence of inflation on leverage diminished after the crisis. As a rule, inflation in the post-crisis period is uncertain due to the low collective consumption and the uncertain magnitude and duration of the crisis. It should not be forgotten that some restrictions (sanctions) were imposed on a number of Russian companies. Under such conditions, the lowering of inflation leads to low short-term interest rates and the increase of demand for credit. Thus, following these consequences it is implied that not only geopolitical and macroeconomic environment, but also microeconomic factors should be considered when making capital structure decisions.

Following the complete sample (table 10), the dynamics of stock market capitalization has a significant and positive influence on leverage. This value seems very interesting, because no significant impact was observed during the whole study period, and as opposed to the pre-crisis period, the post-crisis influence only increased. Considering the consequences of the financial crisis and the imposed restrictions, the issuing companies probably overviewed the capital structure formation strategies in a part of external investment, based on increased stock market volatility, reduction of stock trading, deterioration of capitalization values and weakening of the economic securitization. Thus, it may be concluded that geopolitical conditions create background and environment of the market, or to put it another way, the 
stock markets change only in the direction specified by macroeconomic indicators. In general, it can be said that the influence of the macroeconomic environment is increasing after the crisis.

\section{Regression Analysis Results}

This study considers the influence of the financial crisis in 2014 on the capital structure of public joint stock companies belonging to 7 leading Russian industries. The study involved 49 companies for the period from 2011 to 2017. For a more detailed insight into the influence of the crisis, the pre-crisis and post-crisis samples were examined. The comprehension of nature and degree of correlation between key determinants and financial leverage under crisis conditions brings important outcomes for managers and can let companies take precautionary measures to mitigate the lack of internal and external sources of financing. This study took the first step forward in searching for the efficient capital structure formation.

Based on the empirical findings, it may be concluded that it is impractical to use main capital structure theories under current conditions of financialization of the economy, uncertainty in the Russian financial market development, in the light of specific sectoral orientation of the domestic economy, and it can lead to inaccurate and incorrect values. To obtain more significant and reliable results, the studies should involve the selection of external and specific factors, a large sample volume for the long time interval, as well as the regression model construction.

Thus, it is possible to model a general policy for companies operating in crisis conditions: with an increase in the level of profitability by 1 point, an increase in the leverage ratio follows. On the contrary, the negative impact on the leverage is a decrease in the possibility of companies' growth.

Based on the complete sample of model No. 4 (table 10) for the entire study period, the regression model is presented as an equation:

$$
\begin{aligned}
& Y=3,36416-0,54321 * X_{1}+0,44213 * X_{2}+2,84035 * X_{3}-0,26461 * X_{4}- \\
& 0,02483 * X_{5}-1,58386 * X_{6}+0,05916 * X_{7}-0,06318 * X_{8}-0,02532 * X_{9}
\end{aligned}
$$

where:

Y - financial leverage ratio (TDTA);

X1 - growth potential (GTA);

X2 - materiality (NFATA);

X3 - return on assets (ROA);

X4 - company size;

X5 - liquidity (CL); 
X6 - financial risk (FR);

X7 - dynamics of the Russian stock market capitalization to GDP (SMC);

X8 - annual GDP growth (GDPG);

X9 - inflation rate (INFL).

The significance test of the model coefficients based on t-statistics showed statistically significant variables of growth potential and profitability. The significance of the regression equation was evaluated with F-test, which showed that the model's quality is principally good. The determination coefficient $\mathrm{R} 2=0.741$ is quite high. The model explains the behavior of the $\mathrm{Y}$-index by $74.1 \%$. The standard error amounts to just 3.037. Testing for the residual autocorrelation with $5 \%$ critical values of the DurbinWatson statistics showed that there is no residual autocorrelation.

Based on the presented model, a direct correlation is established between leverage and profitability, which is inconsistent with the pecking order theory, but corresponds to the trade-off theory. The detected inverse correlation between leverage and growth potential determinants corresponds to the trade-off theory and is inconsistent with the pecking order theory.

In favorable conditions for the functioning of the Russian economy, companies should build their policies based on their size, taking into account the conflicting impact of macroeconomic factors on the capital structure. In particular, if the company size ratio increases by 1 point, there will be a proportional increase in leverage.

Based on the complete sample of model No. 4 (table 10) for the period from 2011 to 2013, the regression model is presented as an equation:

$Y=-152,709-0,566 \times X_{1}-0,530 \times X_{2}-1,726 \times X_{3}-1,248 * X_{4}-0,029 * X_{5}-13,086 * X_{6}-$

$2,448 * X_{7}+21,183 * X_{8}+0,952 * X_{9}$

where:

Y - financial leverage ratio (TDTA);

X1 - growth potential (GTA);

X2 - materiality (NFATA);

X3 - return on assets (ROA);

X4 - company size;

X5 - liquidity (CL); 
X6 - financial risk (FR);

X7 - dynamics of the Russian stock market capitalization to GDP (SMC);

X8 - annual GDP growth (GDPG);

X9 - inflation rate (INFL).

The significance test of the model coefficients based on t-statistics showed that the variables of company size, financial risk and all macroeconomic factors (GDP growth, inflation and dynamics of the Russian stock market capitalization) are significant. The significance of the regression equation was evaluated with F-test, which showed that the model's quality is principally good. The determination coefficient R2=0,928 is quite high. The model explains the behavior of the $Y$-index by $92,8 \%$. As compared with the previous model, the standard error decreased and amounts to 2,249. Testing for the residual autocorrelation with $5 \%$ critical values of the Durbin-Watson statistics showed that there is no residual autocorrelation.

Based on this model, a positive correlation is established between leverage and company size before the financial crisis, which corresponds to the trade-off theory, but is inconsistent with the pecking order theory.

Macroeconomic factors are extremely important for the determination of capital structure and show various degree and nature of influence on financial leverage.

After the crisis, companies should be guided by the following scenario for building a capital structure: reducing the company size by 1 point has a positive effect on leverage. It is also necessary to pay attention to macroeconomic indicators.

Based on the complete sample of model No. 4 (table 10) for the period from 2015 to 2017, the regression model is presented as an equation.

$Y=-72,2164-0,2300 * X_{1}-1,5626 * X_{2}+0,0810 * X_{3}-1,1950 * X_{4}-0,0040 *$

$X_{5}-12,3947 * X_{6}+29,9779 * X_{7}+5,5896 * X_{8}+1,4529 * X_{9}$

where:

Y - financial leverage ratio (TDTA);

X1 - growth potential (GTA);

X2 - materiality (NFATA);

X3 - return on assets $(R O A)$;

X4 - company size; 
X5 - liquidity (CL);

X6 - financial risk (FR);

X7 - dynamics of the Russian stock market capitalization to GDP (SMC);

X8 - annual GDP growth (GDPG);

X9 - inflation rate (INFL).

The significance test of the model coefficients based on t-statistics showed that all variables are significant, except for company growth potential, profitability and liquidity. The significance of the regression equation was evaluated with F-test, which showed that the model's quality is principally good. The determination coefficient R2 $=0.870$ is quite high. The model explains the behavior of the $\mathrm{Y}$-index by $87 \%$. As compared with the previous model, the standard error amounts to 3.084 . Testing for the residual autocorrelation with $5 \%$ critical values of the Durbin-Watson statistics showed that there is no residual autocorrelation.

After the financial crisis, the inverse correlation was established between leverage and company size variable, which is inconsistent with the trade-off theory and corresponds to the pecking order theory. Macroeconomic factors are also significant, but the variable of stock market development increased significantly as compared with the pre-crisis period.

\section{Conclusions}

The main findings of this study, which are of applied relevance for Russian public companies in the leading economic sectors, are as follows.

The detected significance of leverage and company size during the entire study period proves that both during and after the crisis the company size should be taken into account when making decisions on the optimal capital structure formation. Moreover, based on the established direct correlation between leverage and company size before the crisis, it may be concluded that large companies had more opportunities for obtaining a loan in the conditions of relative certainty. But since 2014, the inverse correlation between debt load and company size proves that larger companies, whose securities were admitted to the stock exchange trading, have difficulties in increasing the debt load under harsh economic restrictions (sanctions) and highly volatile domestic stock market. This conclusion may serve as a recommendation on the business scale reduction for companies that plan to implement investment decisions mainly through the debt financing. In other terms, large companies probably pursue a less aggressive market policy after the financial crisis and therefore need less debt funds.

The insignificant correlation between leverage and company growth potential proves that the financial crisis does not exert a considerable impact on the corporate financing policy aimed at the expansion of their business, growth of prospects and improvement of competitiveness. The companies' policies are 
based predominantly on the fixed asset financing from their own sources, which is explained by potentially high agency costs and corporate management standards of the analyzed joint stock companies.

Based on the established concept of positive impact of leverage on ROA (return on assets) and the significant positive correlation between leverage and ROA established during testing the model, the following conclusion may be drawn up. Public joint stock companies prefer to build up ROA by increasing the financial leverage effect. Moreover, the financial crisis had a significant impact on the ROA growth predominantly used by the analyzed companies.

Due to the continuity of most industrial technologies and aggressive nature of the environment where the fixed assets of joint stock companies from key industries circulate, it would be logical to recommend such industrial companies to use high depreciation rates for objects that are being operated in an aggressive environment or in the conditions of increased shift system. This would significantly reduce the risks of financial difficulties.

As follows from the conducted analysis, debt is mainly conditioned by the pre-crisis demand, when it is assumed that supply has the greatest elasticity and can satisfy any potential demand. Since 2014, supply and demand are also very important for the determination of financial leverage ratio. This is explained by the fact that in the post-crisis period, creditors began to focus more on company size in the light of high concern over bankruptcy risks.

All models demonstrated the increase of financial leverage ratio in the post-crisis period, which proves the influence of the crisis on the corporate capital structure. It is supposed that, as a rule, companies have to borrow more funds during and after crises, as their lower rate of return does not generate sufficient amount of internal resources for the maintenance of their long-term growth potential.

The detected significant influence of macroeconomic factors on the capital structure formation before, during and after the crisis proves that managers make financial decisions according to the source of financing, based on macroeconomic conditions and the specific character of their industry. The findings indicate a certain importance of the national stock market development insofar as it represents a developing and open market for external investors. The inflation rate has a positive influence on the developing market. The influence of GDP growth on leverage is strong and negative in the pre-crisis period, but significant and positive in the post-crisis period. As follows from the presented analysis, the traditional theories of capital structure do not correlate with empirical values.

External factors determining the capital structure are very important for financial decisions. With the help of information on the power and direction of such influence, managers can effectively and accurately choose a source of financing for stable and successful development of the company. Moreover, under economic restrictions and sanctions imposed on a number of large public joint stock companies from the leading Russian economic sectors in 2014, as well as under the conditions of highly volatile domestic stock market after the financial crisis, companies should place more emphasis on the macroeconomic 
environment characteristics during the formation of an optimal capital structure. This is confirmed by the fact that the dynamics of stock market capitalization exerts a strong and positive influence on leverage after the financial crisis.

\section{References}

Adair, F., Adaskou, M. 2015, Trade-Off Theory vs. pecking order theory and the determinants of corporate leverage: evidence from a panel data analysis upon French SMEs (2002-2010), Cogent Economics \& Finance Vol. 3, No. 1, pp. 1-12.

Akbar, S., Rehman, S.U. \& Ormrod, P., 2013. The impact of recent financial shocks on the financing and investment policies of UK private firms. International Review of Financial Analysis, 26, pp.59-70.

Ang, J.S., Chua, J.H. \& McConnell, J.J., 1982. The Administrative Costs of Corporate Bankruptcy: A Note. The Journal of Finance, 37(1), pp.219-226.

Antoniou, A., Guney, Y. \& Paudyal, K., 2008. The Determinants of Capital Structure: Capital MarketOriented versus Bank-Oriented Institutions. The Journal of Financial and Quantitative Analysis, 43(1), pp.59-92.

Bancel, F., and U. R. Mittoo (2004), Cross-Country Determinants of Capital Structure Choice: A Survey of European Firms, Financial Management, Vol. 33, Nr. 4, pp. 103- 132.

Bastos, D. D., Nakamura, W. T., \& Basso, L. F. C. 2009. Determinants of capital structure of publicly-traded companies in Latin America: the role of institutional and macroeconomic factors, Journal of international finance and economics, 9(3), 24-39.

Beattie, V., Goodacre, A., \& Thomson, S. J. (2006). Corporate financing decisions: UK survey evidence. Journal of Business Finance and Accounting, 33(9-10), 1402-1434.

Belkhir, M., Maghyereh, A. \& Awartani, B., 2016. Institutions and Corporate Capital Structur in the MENA Region. Emerging Markets Review.

Bennett, M. \& Donnelly, R. 1993. The determinants of capital structure: some UK evidence. British Accounting Review. 25(1), 43-59.

Bevan, A.A. \& Danbolt, J., 2002. Capital Structure and Its Determinants in the United Kingdom: A Decompositional Analysis. Applied Financial Economics, 12(3), pp.37-41.

Blank, I.A. Financial resources management. 2017. M .: Omega-L, 158 p.

Bocharov V.V. 2009. The financial analysis. 2nd ed. SPb.: Peter. - 240 p. 
Bokpin, G. A. 2009. Macroeconomic development and capital structure decisions of firms: evidence from emerging market economies, Studies in economics and finance, 26(2), 129-142.

http://dx.doi.org/10.1108/10867370910963055

Booth, L. et al., 2001. Capital structures in developing countries. The Journal of Finance, 56(1), pp.87130.

Bradley, M., Jarrell, G. \& Kim, E.H., 1984. On the Existence of an Optimal Capital Structure: Theory and Evidence. Journal of Finance, 39(3), p.857.

Brealey, R. and Myers, S. 2003. Principles of Corporate Finance. International Edition. McGraw-Hill, 7 edition.

Brierly P., Bunn P. 2005. The determination of UK Corporate Capital Gearing. Bank of England, Quarterly Bulletin, Vol. 45, No. 3, pp. 356.

Brigham, E. \& Ehrhardt, M. 2008. Financial Management: Theory and Practice. 12th ed., USA, Thomson Learning.

Camara, 0. 2012. Capital structure adjustment speed and macroeconomic conditions: U.S. MNCs and DCs, International research journal of finance and economics, 84, pp. 106-120.

Cassar G., Holmes S. 2003. Capital Structure and Financing of SMEs: Australian Evidence. Journal of Accounting and Finance, 43(2), pp. 123- 147.

Chen J.J. 2003. Determinants of capital structure of Chineselisted companies. Journal of Business Research, vol.57, pp. 1341-1351.

Chkir, I., Cosset J.C. 2001. Diversification Strategy and Capital Structure of Multinational Corporations. Journal of Multinational Financial Management, 11, pp. 7-37

DeAngelo, H., Masulis, R.W. (1980), Optimal Capital Structure under Corporate and Personal Taxation, Journal of Financial Economics, Vol. 8, Nr. 1, pp. 3-29.

Deesomsak, R., Paudyal, K. \& Pescetto, G., 2004. The determinants of capital structure: Evidence from the Asia Pacific region. Journal of Multinational Financial Management, 14(4-5), pp.387-405.

Deloof, M., Su, J. (2003), Does working capital management affect profitability of Belgian firms?, Journal of Business, Finance and Accounting, 3(40) (2003) 573-587.

Dincergok, B., \& Yalciner, K. 2011. Capital structure decisions of manufacturing firms' in developing countries, Middle Eastern finance and economics, 12, April, 2011, pp. 86-100.

Donaldson, G. 1981, Corporate Debt Capacity. Boston. Harvard Graduate School of Business. 
Dong, H.P. 2010, The relationship between Working Capital Management and Profitability: A Vietnam Case, International Research Journal of Finance and Economics, 49 (2010) 42-57.

Duan, H., Chik bin, A. R. \& Liu, C. 2012. Institutional environment and capital structure: evidence from private listed enterprises in China, International journal of financial research, 3(1), 15-21.

Duchin, R., Ozbas, O. and Sensoy, B.A., 2010. Costly external finance, corporate investment, and the subprime mortgage credit crisis. Journal of Financial Economics, 97(3), pp.418- 435.

Eljelly, A. 2004, Liquidity-Profitability Tradeoff: An empirical investigation in an Emerging Market, International Journal of Commerce \& Management, 2(14). 48-61.

Esperanca J.P, Mohamed A.G. 2003. Corporate Debt Policy of Small Firms: an Empirical (re)examination. Journal of Small Business and Enterprise Development, 10(1), pp. 62-80.

Fama, E. F., and K. R. French (2002), Testing Trade-Off and Pecking Order Predictions About Dividends and Debt, Review of Financial Studies, Vol. 15, Nr. 1, pp. 1-33.

Fama, E. F. and M. Jensen. 1983. Separation of Ownership and Control. Journal of Law and Economics, Vol. 26, Nr. 2, pp. 301-326.

Fan, J.P.H., Titman, S. \& Twite, G., 2012. An International Comparison of Capital Structure and Debt Maturity Choices. Journal of Financial and Quantitative Analysis, 47(01), pp.23-56.

Fedyk, V. 2014, CEO overconfidence: an alternative explanation for corporate financing decisions, Working Papers, Stanford University retrieved from

https://economics.stanford.edu/sites/default/files/publications/valeriafedykhonors-thesismay2014.pdf

Frank, M. Z. and Goyal, V. K. 2009. Capital structure decisions: which factors are reliably important? Financial Management, Vol. 38, No 1, 1-37.

Gaud, P., M. Hoesli and A. Bender. 2005. Debt-Equity Choice in Europe. FAME - International Center for Financial Asset Management and Engineering, Research Paper Nr. 152.

Gajurel, D. P. 2006. Macroeconomic influences on corporate capital structure. Available at SSRN: http://ssrn.com/abstract=899049 or http://dx.doi.org/10.2139/ssrn.899049

Grossman Sanford, J. \& Hart, O., 1982. Corporate financial structure and Managerial incentives J. McCall, ed., Chicago: The Economics of Information and Uncertainty.

Gubanov, O. V. 2007. Substantiation of the existence of the problem of forming the optimal capital structure of an enterprise. Modern problems of economics, sociology and law. - SPb .: SPbGIEU.

Hackbarth, D. 2008, Managerial traits and capital structure decisions, Journal of Financial and Quantitative Analysis Vol. 43, No. 4, pp. 843-881. 
Hall, G., Hutchinson, P. \& Michaelas, N. 2000. Industry effects on the determinants of unquoted SMEs' capital structure, International journal of the economics of business, 7(3), 297-312. http://dx.doi.org/10.1080/13571510050197203

Hanousek, J. and A. Shamshur, A. 2011, A Stubborn Persistence: Is the Stability of Leverage Ratios Determined by the Stability of the Economy?, Journal of Corporate Finance, Vol. 17, Nr. 5, pp. 1360-1376.

Harris M., Raviv A. The Theory of Capital Structure. URL: http://faculty. fullerton. edu/jyang/ Courses/fin332/Literature/harrisRaviv91.pdf.

Harrison, B. \& Widjaja, T.W., 2014. The Determinants of Capital Structure: Comparison between Before and After Financial Crisis. Economic Issues, 19(2), pp.55-82.

Iqbal, A. \& Kume, O., 2014. Impact of Financial Crisis on Firms' Capital Structure in UK, France, and Germany. Multinational Finance Journal, 18(3), pp.240-280.

Jensen, M.C., 1986. Agency costs of free cash flow, corporate finance, and takeovers. The American Economic Review, 76(2), pp.323-329.

Jensen, M.C. \& Meckling, W.H., 1976. Theory of the Firm : Managerial Behavior , Agency Costs and Ownership Structure Theory of the Firm : Managerial Behavior, Agency Costs and Ownership Structure. Journal of Financial Economics, 3(4), pp.305-360.

Judge, A. \& Korzhenitskaya, A., 2012. Credit market conditions and the impact of access to the public debt market on corporate leverage. International Review of Financial Analysis, 25, pp.28-63.

Köksal, B., Orman, C. and Oduncu, A. (2013), Determinants of Capital Structure: Evidence from a Major Emerging Market Economy, Munich Personal RePEc Archive Paper No. 48415.

Kraus, A. \& Litzenberger, R.H., 1973. a State-Preference Model of Optimal Financial Leverage. Journal of Finance, 28(4), pp.911-922.

Kuhnhausen, F. \& Stieber, H., 2014. Determinants of Capital Structure in Non-Financial Companies, Munich Discussion Paper No. 2014-38.

Lisitsa, M. 2002. Capital structure theory: review and addition of models, development of a quantitative concept of a compromise approach for structuring sources of financing for a firm's activities. Investments in Russia. N.11. - P.37-48.

Marsh P. The choice between equity and debt: an empirical study. Journal of Finance, 1982, vol. 37, no.1, pp. 121-144.

Matemilola, B.T., Bany-Ariffin, A.N., McGowan, C.B. Jr. 2012, Trade off theory against pecking order theory of capital structure in a nested model: panel GMM evidence from South Africa, The Global Journal of 
Finance and Economics Vol. 9, No. 2, pp. 133-147.

Metel'skaya, V.V. 2018. Finance and Credit, vol. 24, iss. 37, pp. 2204-2222.

https://doi.org/10.24891/fc.24.10.2204

Modigliani, F. \& Miller, M.H., 1963. Corporate income taxes and the cost of capital: A correction. The American Economic Review, 53(3), pp.433-443.

Morellec, E., 2003. Can Managerial Discretion Explain Observed Leverage Ratios? Review of Financial Studies, 17(1), pp.257-294.

Myers, S.C., 1977. Determinants of corporate borrowing. Journal of Financial Economics, 5(2), pp.147175.

Myers, S. C. 1984, The Capital Structure Puzzle, The Journal of Finance, Vol. 39, Nr. 3, pp 575-592.

Myers, S. C. 2003, Chapter 4: Financing of Corporations, in: G. M. Constantinides, M. Harris and R. M. Stulz (eds.), Handbook of the Economics of Finance. Elsevier, pp. 215- 253.

Myers, S.C. \& Majluf, N.S., 1984. Corporate financing and investment decisions when firms have information that investors do not have. Journal of Financial Economics, 13(2), pp.187-221.

Park, C., Kim, H. 2009, The effect of managerial overconfidence on leverage, International Business \& Economics Research Journal Vol. 8, No. 12, pp. 115-126.

Rajan, R.G. \& Zingales, L., 1995. What Do We Know About Capital Structure - Some Evidence From International Data. Journal of Finance, 50(5), pp.1421-1460.

Rihab, B.A., Lotfi, B.J. 2016, Managerial overconfidence and debt decisions, Journal of Modern Accounting and Auditing Vol. 12, No. 4, pp. 225-241.

Sbeiti, W., 2010. The determinants of capital structure: evidence from the GCC countries. International Research Journal of Finance and Economics, 47, pp.56-82.

Scott, M. \& Bruce, R. 1987. Five stages of growth in small business.

Serrasqueiro, Z., Caetano, A. 2015, Trade-off theory versus pecking order theory: capital structure decisions in a peripheral region of Portugal, Journal of Business Economics and Management Vol. 16, No. 2, pp. 445-466.

Sett, K. \& Sarkhel, J. 2010. Macroeconomic variables, financial sector development and capital structure of Indian private corporate sector during the period 1981-2007. The IUP journal of applied finance, 16(1), 40-56. 
Singhania M., Seth A. 2010. Financial Leverage and Investment Opportunities in India: An Empirical Study, International Research Journal of Finance and Economics, Issue 40. pp. 215-226.

Stoyanova E.S. 2010. Financial management: theory and practice. M.: Perspektiva, 656 p.

Titman, S. and R. Wessels. 1988. The determinants of capital structure choice, Journal of Finance, 43, pp. 1-19.

Volkov, D.L., Nikulin, E.D. 2012. Working capital management: Analysis of the impact of the financial cycle on the profitability and liquidity of companies, Bulletin of St. Petersburg University. series 8. Management. No 2. pp. 3-33.

Warner, J.B., 1977. Bankruptcy costs: Some evidence. The Journal of Finance, 32(2), p.337.

\section{Tables}

Table 1: Review of capital structure factors in the framework of the main theories of capital structure 


\begin{tabular}{|c|c|c|c|c|}
\hline \multicolumn{2}{|l|}{ Trade-off theory } & \multirow{2}{*}{$\begin{array}{c}\text { Factor } \\
\text { affecting } \\
\text { leverage }\end{array}$} & \multicolumn{2}{|c|}{ Pecking order theory } \\
\hline Research & Communication value & & $\begin{array}{l}\text { Communication } \\
\text { value }\end{array}$ & Research \\
\hline $\begin{array}{l}\text { Jensen and Meckling, } 1976 \\
\text { Myers, } 1977 \\
\text { Mel Scot and Richard Bruce, } 1987\end{array}$ & negative & GTA & positive & $\begin{array}{l}\text { Myers and Majluf, } \\
\text { 1984; Frank and } \\
\text { Goyal, } 2008 \\
\text { Hall, Hutchinson, } \\
\text { Michaelas, } 2004\end{array}$ \\
\hline $\begin{array}{l}\text { Titman and Wessels, 1988; Rajan and Zingales, } \\
\text { 1995; Frank and Goyal, 2009 } \\
\text { Grossman and Hart, 1982; Titman and Wessels, } \\
1988\end{array}$ & $\begin{array}{l}\text { positive } \\
\text { negative }\end{array}$ & NFATA & negative & $\begin{array}{l}\text { Frank and Goyal, } \\
2008\end{array}$ \\
\hline Fama and French, 2002 & positive & ROA & negative & $\begin{array}{l}\text { Myers and Majluf, } \\
1984 \\
\text { Cassar, Holmes, } \\
2003\end{array}$ \\
\hline $\begin{array}{l}\text { Warner, 1977; Ang et al., 1982; Titman and } \\
\text { Wessıls, 1988; Chkir and Cosset, 2001; Bevan, } \\
\text { Danbolt, 2002 } \\
\text { Marsh (1982), Bennett } ₫ \text { Donnelly (1993 }\end{array}$ & positive & IPA & $\begin{array}{l}\text { negative (large } \\
\text { companies) } \\
\text { positive (small } \\
\text { and medium } \\
\text { companies) }\end{array}$ & $\begin{array}{l}\text { Fama and Jensen, } \\
\text { 1983; Rajan and } \\
\text { Zingales, } 1995 \\
\text { Cassar, Holmes, } \\
\text { 2003; Esperanca, } \\
\text { Pantzalis, 2003; } \\
\text { Hall, Hutchinson, } \\
\text { Michaelas, } 2004\end{array}$ \\
\hline $\begin{array}{l}\text { Harris and Raviv, 1991; Bancel and Mittoo, 2004; } \\
\text { Brierley and Bunn, 2005; Frank and Goyal, } 2009\end{array}$ & negative & FR & positive & $\begin{array}{l}\text { Frank and Goyal, } \\
2009\end{array}$ \\
\hline Singhania, Seth, 2010 & negative & CL & negative & \\
\hline $\begin{array}{l}\text { Frank and Goyal, 2009; Koksal et al., 2013; } \\
\text { Kuhnhausen and Stieber, 2014; Sett and Sarkhel, } \\
\text { 2010; Hanousek and Shamshur, } 2011\end{array}$ & positive & INFL & $\begin{array}{l}\text { negative } \\
\text { no connection } \\
\text { connection is } \\
\text { in part }\end{array}$ & $\begin{array}{l}\text { Gajurel, } 2006 \\
\text { Bastos, Nakamura } \square \\
\text { Basso (2009) } \\
\text { Frank } \square \text { Goyal, } 2009 \\
\text { Camara (2012 }\end{array}$ \\
\hline Gajurel, 2006 & negative and positive & GDPG & negative & $\begin{array}{lr}\text { Bastos, Nakamura } \\
\text { and Basso, 2009; } \\
\text { Bokpin, 2009; } \\
\text { Dincergok and } \\
\text { Yalciner, 2011; } \\
\text { Camara, 2012 } \\
\end{array}$ \\
\hline $\begin{array}{l}\text { Bokpin, } 2009 \\
\text { Sett, Sarkhel, } 2010 \\
\text { Duan, Chik bin. } \square \text { Liu, } 2012\end{array}$ & $\begin{array}{l}\text { no connection } \\
\text { negative }\end{array}$ & SMC & positive & $\begin{array}{l}\text { Dincergok and } \\
\text { Yalciner, } 2011 \\
\text { Gajurel, 2006 }\end{array}$ \\
\hline
\end{tabular}

\section{Source: Authoring}

Table 2: List of corporations whose securities are traded on the stock exchange 


\begin{tabular}{|c|c|c|}
\hline Conomic sector & Company & Stock code \\
\hline \multirow[t]{7}{*}{$\overline{\text { IGA }}$} & PJSC “Gazprom” & GAZP \\
\hline & PJSC “Oil Company LUKOIL” & LKOH) \\
\hline & PJSC “NOVATEK" & NVTK \\
\hline & PJSC “Surgutneftegas" & SNGS \\
\hline & PJSC “Tatneft” & TATN \\
\hline & PJSC "Oil Company Bashneft" & BANE \\
\hline & PJSC "Transneft" & TRNF \\
\hline \multirow[t]{7}{*}{$\overline{{ }^{7} \mathrm{EC}}$} & PJSC "OGK-2" & OGK2 \\
\hline & PJSC "Inter RAO UES" & ERAO \\
\hline & PJSC "Federal Grid Company of Unified Energy System" & FEES \\
\hline & PJSC "TERRITORIAL GENERATING COMPANY No. 1" & TGK1 \\
\hline & PJSC “Quadra - Power Generation” & TGKD \\
\hline & PJSC “MOSENERGO” & MSNG \\
\hline & PJSC “ROSSETI South" & MRKY \\
\hline \multirow[t]{7}{*}{ SHEMIC } & PJSC “Nizhnekamskneftekhim” & NKNK \\
\hline & PJSC "Uralkali" & URLK \\
\hline & PJSC “Acron” & AKRN \\
\hline & JSC “UHP” & UHP \\
\hline & PJSC "Kuibyshevazot" & KUBAZ \\
\hline & PJSC “Ufaorgsintez" & UFAZ \\
\hline & PJSC “Togliattyazot" & TOLAZ \\
\hline \multirow[t]{7}{*}{ IGRO } & PJSC “Rusagro" & RAGRO \\
\hline & PJSC “Cherkizovo Group” & GCHE \\
\hline & JSC “Kuban Steppe" & KUBST \\
\hline & PJSC “FOSAGRO” & FOSAGRO \\
\hline & PJSC “Abrau-Durso" & ABRDS \\
\hline & PJSC “Beluga” & BEL \\
\hline & PJSC "Agrofirma Mcenskaya " & AGROMC \\
\hline \multirow[t]{7}{*}{$\overline{E L E}$} & PJSC “Mobile TeleSystems" & MTSS \\
\hline & PJSC “MegaFon" & MFON \\
\hline & PJSC “ROSSETI" & RSTI \\
\hline & PJSC “Rostelecom” & RTKM \\
\hline & PJSC “VimpelCom” & VPKM \\
\hline & PJSC “Tattelekom” & TTKM \\
\hline & PJSC "Central Telegraph" & CTELE \\
\hline \multirow[t]{7}{*}{$\overline{\text { METALL }}$} & PJSC "Mining and Metallurgical Company NORILSK NICKEL" & GMKN \\
\hline & PJSC “SEVERSTAL” & CHMF \\
\hline & PJSC “Magnitogorsk Iron \& Steel Works" & MAGN \\
\hline & PJSC “VSMPO-AVISMA Corporation” & VSMO \\
\hline & PJSC “Pipe Metallurgical Company” & TRMC \\
\hline & PJSC “Chelyabinsk Metallurgical Plant" & CHMK \\
\hline & PJSC “Chelyabinsk Pipe-Rolling Plant” & CHER \\
\hline \multirow[t]{7}{*}{ RANS } & PJSC “Aeroflot - Russian Airlines" & AFLT \\
\hline & PJSC “UTair Aviation” & UTAR \\
\hline & PJSC “Center for Cargo Container Traffic TransContainer" & TRCN \\
\hline & JSC “Russian Railways” & RZD \\
\hline & PJSC “SVH- FREIGHT" & SVFR \\
\hline & FAR-EASTERN SHIPPING COMPANY PLC. & FESH \\
\hline & North-Western Shipping Co. & SZPR \\
\hline
\end{tabular}

\section{Source: Authoring}

Table 3: Descriptive study sample statistics for independent and dependent variables (mean values) 


\begin{tabular}{|c|c|c|c|c|c|c|c|c|c|c|}
\hline & TDTA & GTA & NFATA & ROA & IPA & CL & FR & SMC & GDPG & INFL \\
\hline \multicolumn{11}{|c|}{ Full sample 2011-2017 } \\
\hline Mean & 1.73 & 0.16 & 0.70 & 0.06 & 0.88 & 3.47 & 0.79 & 38.43 & 0.96 & 7.33 \\
\hline S.D. & 3.12 & 0.84 & 0.61 & 0.16 & 0.69 & 6.42 & 0.14 & 6.83 & 2.66 & 3.59 \\
\hline Min & -8.24 & -11.54 & 0.00 & -1.41 & -6.32 & 0.29 & 0.10 & 29.00 & -3.70 & 2.52 \\
\hline Max & 31.11 & 1.24 & 4.84 & 0.85 & 3.79 & 43.16 & 1.00 & 50.00 & 4.30 & 12.91 \\
\hline \multirow[t]{2}{*}{ Median } & 0.86 & 0.31 & 0.63 & 0.06 & 0.88 & 1.58 & 0.81 & 37.00 & 1.30 & 6.45 \\
\hline & TDTA & GTA & NFATA & $\mathrm{ROA}$ & IPA & CL & FR & SMC & GDPG & INFL \\
\hline \multicolumn{11}{|c|}{ Pre-crisis 2011-2013 } \\
\hline Mean & 1.73 & 0.20 & 0.72 & 0.04 & 0.77 & 2.86 & 0.79 & 40.67 & 3.00 & 6.38 \\
\hline S.D. & 2.92 & 0.57 & 0.65 & 0.19 & 0.75 & 5.30 & 0.14 & 8.14 & 1.54 & 0.25 \\
\hline Min & 0.004 & -1.94 & 0.00 & -1.41 & -6.32 & 0.34 & 0.19 & 35.00 & 1.30 & 6.10 \\
\hline Max & 25.80 & 1.24 & 4.84 & 0.30 & 3.42 & 43.16 & 1.00 & 50.00 & 4.30 & 6.58 \\
\hline \multirow[t]{2}{*}{ Median } & 0.86 & 0.37 & 0.62 & 0.06 & 0.87 & 1.67 & 0.82 & 37.00 & 3.40 & 6.45 \\
\hline & TDTA & GTA & NFATA & ROA & IPA & CL & FR & $\mathrm{SMC}$ & GDPG & INFL \\
\hline \multicolumn{11}{|c|}{ Post-crisis 2015-2017 } \\
\hline Mean & 1.62 & 0.09 & 0.69 & 0.08 & 0.99 & 3.88 & 0.79 & 39.33 & -1.00 & 6.94 \\
\hline S.D. & 3.32 & 1.10 & 0.55 & 0.13 & 0.62 & 6.93 & 0.14 & 4.51 & 2.61 & 5.37 \\
\hline Min & -8.24 & -11.54 & 0.00 & -0.23 & -0.11 & 0.29 & 0.22 & 35.00 & -3.70 & 2.52 \\
\hline Max & 31.11 & 1.00 & 4.58 & 0.85 & 3.79 & 36.07 & 1.00 & 44.00 & 1.50 & 12.91 \\
\hline Median & 0.76 & 0.28 & 0.63 & 0.05 & 0.90 & 1.46 & 0.80 & 39.00 & -0.80 & 5.38 \\
\hline
\end{tabular}

Source: Authoring

Table 4: Descriptive study sample statistics for independent and dependent variables by year (mean values)

\begin{tabular}{rcccccccccc}
\hline Year & TDTA & GTA & NFATA & ROA & IPA & CL & FR & SMC & GDPG & INFL \\
\hline 2011 & 0.86 & 0.29 & 0.87 & 0.08 & 0.76 & 2.77 & 0.79 & 50.00 & 4.30 & 6.10 \\
\hline 2012 & 2.98 & 0.30 & 0.75 & 0.08 & 0.74 & 1.94 & 0.78 & 37.00 & 3.40 & 6.58 \\
\hline 2013 & 2.42 & -0.10 & 0.60 & 0.03 & 1.09 & 4.07 & 0.78 & 35.00 & 1.30 & 6.45 \\
\hline 2014 & 1.87 & -0.18 & 0.56 & 0.02 & 1.10 & 4.08 & 0.79 & 29.00 & 0.70 & 11.36 \\
\hline 2015 & 1.17 & 0.43 & 0.54 & 0.11 & 0.66 & 5.85 & 0.82 & 35.00 & -3.70 & 12.91 \\
\hline 2016 & 1.15 & 0.39 & 0.74 & 0.08 & 0.77 & 3.34 & 0.84 & 44.00 & -0.80 & 5.38 \\
\hline 2017 & 2.44 & -0.10 & 0.91 & 0.02 & 0.81 & 2.26 & 0.76 & 39.00 & 1.50 & 2.52 \\
\hline
\end{tabular}

\section{Source: Authoring}

Table 5: Descriptive statistics of a sample of research of averages by branches of the economy 


\begin{tabular}{lccccccc}
\hline & TDTA & GTA & NFATA & ROA & IPA & CL & FR \\
\hline Pre-crisis & $2011-2013$ & & & & & \\
\hline OIGA & 1.26 & 0.49 & 0.65 & 0.13 & 0.74 & 3.38 & 0.82 \\
\hline FEC & 0.66 & 0.31 & 0.52 & -0.02 & 0.95 & 2.53 & 0.86 \\
\hline CHEMIC & 1.07 & 0.51 & 1.05 & 0.15 & 0.63 & 2.74 & 0.82 \\
\hline AGRO & 1.61 & 0.28 & 0.42 & 0.07 & 0.56 & 4.59 & 0.77 \\
\hline TELE & 1.63 & -0.19 & 0.57 & -0.02 & 1.03 & 2.97 & 0.81 \\
\hline METALL & 2.31 & 0.3 & 0.62 & 0.03 & 0.88 & 2.05 & 0.77 \\
\hline TRANS & 3.69 & 0.06 & 1.39 & 0.04 & 0.34 & 1.54 & 0.69 \\
\hline & & & & & & & \\
\hline Post-crisis & $2015-2017$ & & & & & \\
\hline OIGA & 1.57 & 0.41 & 0.56 & 0.10 & 0.84 & 3.34 & 0.84 \\
\hline FEC & 1.35 & -0.15 & 0.43 & 0.03 & 1.07 & 3.56 & 0.85 \\
\hline CHEMIC & 1.51 & 0.21 & 0.97 & 0.13 & 1.84 & 2.98 & 0.81 \\
\hline AGRO & 0.85 & 0.53 & 0.37 & 0.1 & 0.7 & 7.6 & 0.84 \\
\hline TELE & 1.89 & -0.21 & 0.56 & 0.07 & 1.23 & 5.2 & 0.8 \\
\hline METALL & 4.07 & 0.25 & 0.78 & 0.11 & 0.61 & 1.48 & 0.72 \\
\hline TRANS & -0.11 & 0.03 & 1.25 & 0.02 & 1.28 & 1.41 & 0.71 \\
\hline
\end{tabular}

Source: Authoring

Table 6: The matrix of paired correlation coefficients, used observations -393 , the length of the time series $=7$ 


\begin{tabular}{|c|c|c|c|c|c|c|c|c|c|}
\hline \multicolumn{10}{|c|}{ Full sample 2011-2017 } \\
\hline & GTA & NFATA & $\mathrm{ROA}$ & IPA & $\mathrm{CL}$ & FR & SMC & GDPG & INFL \\
\hline GTA & 1.00 & & & & & & & & \\
\hline NFATA & 0.001 & 1.00 & & & & & & & \\
\hline ROA & 0.07 & 0.15 & 1.00 & & & & & & \\
\hline IPA & -0.37 & -0.16 & -0.09 & 1.00 & & & & & \\
\hline CL & 0.33 & -0.20 & -0.24 & -0.15 & 1.00 & & & & \\
\hline FR & 0.32 & -0.52 & 0.00 & -0.13 & 0.41 & 100 & & & \\
\hline SMC & 0.02 & -0.02 & 0.08 & -0.05 & -0.02 & 0.06 & 1.00 & & \\
\hline GDPG & 0.09 & 0.01 & -0.05 & -0.13 & -0.05 & 0.04 & 0.39 & 1.00 & \\
\hline INFL & -0.07 & 0.01 & -0.03 & 0.01 & 0.01 & -0.05 & -0.55 & -0.57 & 1.00 \\
\hline
\end{tabular}

Pre-crisis 2011-2013

\begin{tabular}{lccccccccc}
\hline & GTA & NFATA & ROA & IPA & CL & FR & SMC & GDPG & INFL \\
\hline GTA & 1.00 & & & & & & & & \\
\hline NFATA & 0.03 & 1.00 & & & & & & & \\
\hline ROA & -0.11 & 0.18 & 1.00 & & & & & & \\
\hline IPA & -0.43 & -0.17 & -0.05 & 1.00 & & & & & \\
\hline CL & 0.39 & -0.17 & -0.63 & -0.14 & 1.00 & & & & \\
\hline FR & 0.33 & -0.45 & -0.15 & -0.005 & 0.32 & 1.00 & & & \\
\hline SMC & 0.06 & -0.06 & 0.06 & -0.12 & 0.03 & 0.10 & 1.00 & & \\
\hline GDPG & -0.04 & -0.03 & 0.12 & -0.04 & -0.05 & 0.03 & 0.81 & 1.00 & \\
\hline INFL & -0.11 & 0.07 & 0.00 & 0.15 & -0.08 & -0.13 & -0.93 & -0.53 & 1.00 \\
\hline
\end{tabular}

Post-crisis 2015-2017

\begin{tabular}{lccccccccc}
\hline & GTA & NFATA & ROA & IPA & CL & FR & SMC & GDPG & INFL \\
\hline GTA & 1.00 & & & & & & & & \\
\hline NFATA & -0.02 & 1.00 & & & & & & & \\
\hline ROA & 0.24 & 0.09 & 1.00 & & & & & & \\
\hline IPA & -0.33 & -0.14 & -0.22 & 1.00 & & & & & \\
\hline CL & 0.30 & -0.21 & 0.17 & -0.19 & 1.00 & & & & \\
\hline FR & 0.32 & -0.58 & 0.15 & -0.28 & 0.48 & 1.00 & & & \\
\hline SMC & 0.04 & -0.03 & 0.14 & 0.08 & -0.02 & 0.05 & 1.00 & & \\
\hline GDPG & 0.11 & -0.03 & 0.01 & -0.03 & 0.04 & 0.07 & 0.50 & 1.00 & \\
\hline INFL & -0.10 & 0.03 & -0.04 & 0.01 & -0.03 & -0.07 & -0.65 & -0.98 & 1.00 \\
\hline
\end{tabular}

The matrix of multiple correlation coefficients, observations used - 3920, time series length $=7, p<0.05$ 


\begin{tabular}{|c|c|c|c|c|c|c|c|c|c|}
\hline & GTA & NFATA & ROA & IPA & $\mathrm{CL}$ & FR & SMC & GDPG & INFL \\
\hline \multicolumn{10}{|c|}{ Full sample 2011-2017 } \\
\hline GTA & 1.00 & & & & & & & & \\
\hline NFATA & 0.98 & 1.00 & & & & & & & \\
\hline ROA & 0.99 & 0.99 & 1.00 & & & & & & \\
\hline IPA & 0.97 & 0.98 & 0.99 & 1.00 & & & & & \\
\hline CL & 0.64 & 0.59 & 0.60 & 0.59 & 1.00 & & & & \\
\hline FR & 0.99 & 0.99 & 1.00 & 0.99 & 0.62 & 1.00 & & & \\
\hline SMC & 0.89 & 0.89 & 0.90 & 0.88 & 0.53 & 0.90 & 1.00 & & \\
\hline GDPG & 0.80 & 0.81 & 0.82 & 0.81 & 0.50 & 0.82 & 0.59 & 1.00 & \\
\hline \multirow[t]{2}{*}{ INFL } & 0.44 & 0.44 & 0.45 & 0.44 & 0.26 & 0.45 & 0.56 & 0.08 & 1.00 \\
\hline & GTA & NFATA & $\mathrm{ROA}$ & IPA & $\mathrm{CL}$ & FR & SMC & GDPG & INFL \\
\hline \multicolumn{10}{|c|}{ Pre-crisis 2011-2013 } \\
\hline GTA & 1.00 & & & & & & & & \\
\hline NFATA & 0.99 & 1.00 & & & & & & & \\
\hline ROA & 1.00 & 1.00 & 1.00 & & & & & & \\
\hline IPA & 0.99 & 0.99 & 0.99 & 1.00 & & & & & \\
\hline CL & 0.83 & 0.81 & 0.81 & 0.81 & 1.00 & & & & \\
\hline FR & 1.00 & 1.00 & 1.00 & 1.00 & 0.82 & 1.00 & & & \\
\hline SMC & 0.98 & 0.98 & 0.99 & 0.98 & 0.80 & 0.99 & 1.00 & & \\
\hline GDPG & 1.00 & 1.00 & 1.00 & 1.00 & 0.82 & 1.00 & 0.98 & 1.00 & \\
\hline \multirow[t]{2}{*}{ INFL } & 0.57 & 0.57 & 0.57 & 0.56 & 0.48 & 0.57 & 0.67 & 0.55 & 1.00 \\
\hline & GTA & NFATA & ROA & IPA & CL & FR & SMC & GDPG & INFL \\
\hline \multicolumn{10}{|c|}{ Post-crisis 2015-2017 } \\
\hline GTA & 1.00 & & & & & & & & \\
\hline NFATA & 0.99 & 1.00 & & & & & & & \\
\hline ROA & 0.99 & 1.00 & 1.00 & & & & & & \\
\hline IPA & 0.98 & 0.99 & 1.00 & 1.00 & & & & & \\
\hline CL & 0.76 & 0.72 & 0.74 & 0.72 & 1.00 & & & & \\
\hline FR & 0.99 & 1.00 & 1.00 & 1.00 & 0.74 & 1.00 & & & \\
\hline SMC & 0.96 & 0.96 & 0.97 & 0.96 & 0.72 & 0.97 & 1.00 & & \\
\hline GDPG & 0.84 & 0.85 & 0.85 & 0.85 & 0.62 & 0.85 & 0.69 & 1.00 & \\
\hline INFL & 0.79 & 0.79 & 0.79 & 0.79 & 0.57 & 0.79 & 0.84 & 0.47 & 1.00 \\
\hline
\end{tabular}

Source: Authoring

Table 7: Model 1: Pooled Least square method (LSM), used observations - 393, the length of the time series = 7 Full sample 2011-2017

\begin{tabular}{lllll}
\hline & Beta & Std.Err. & $\mathrm{t}(386)$ & $\mathrm{p}$-level \\
\hline const & 2.76657 & 0.665528 & 4.15696 & 0.000040 \\
GTA & -0.54930 & 0.213675 & -2.57073 & 0.010522 \\
NFATA & 0.48128 & 0.261337 & 1.84161 & 0.066299 \\
ROA & 2.75008 & 0.907614 & 3.03001 & 0.002610 \\
IPA & -0.26683 & 0.234216 & -1.13926 & 0.255610 \\
CL & -0.02613 & 0.028012 & -0.93280 & 0.351508 \\
FR & -1.142031 & 0.870105 & -1.63234 & 0.103422 \\
\hline
\end{tabular}




\begin{tabular}{ll}
\hline Multiple R & 0.85949552 \\
R2 & 0.7387254 \\
Adjusted R2 & 0.73467139 \\
F $(6,386)$ & 181.90 \\
Standard error of estimate & 3.037638975 \\
Durbin-Watson d & 1.112130 \\
Serial Corr. & 0.443626 \\
\hline
\end{tabular}

Pre-crisis 2011-2013

\begin{tabular}{lllll}
\hline & Beta & Std.Err. & $\mathrm{t}(162)$ & $\mathrm{p}$-level \\
\hline const & 3.34412 & 0.923540 & 3.62098 & 0.000392 \\
GTA & -0.87164 & 0.470941 & -1.85084 & 0.066013 \\
NFATA & 0.75272 & 0.342977 & 2.19466 & 0.029611 \\
ROA & 3.99632 & 1.240021 & 3.22278 & 0.001535 \\
IPA & -0.72615 & 0.312112 & -2.32658 & 0.021226 \\
CL & 0.07380 & 0.056715 & 1,30118 & 0.195043 \\
FR & -2.26044 & 1.298551 & -1.74074 & 0.083628 \\
\hline
\end{tabular}

\begin{tabular}{ll}
\hline Multiple R & 0.94320787 \\
R2 & 0.88964109 \\
Adjusted R2 & 0.88555373 \\
F $(6,386)$ & 217.6563 \\
Standard error of estimate & 2.765147391 \\
Durbin-Watson d & 1.029756 \\
Serial Corr. & 0.485089 \\
\hline
\end{tabular}

Post-crisis 2015-2017

\begin{tabular}{lllll}
\hline & Beta & Std.Err. & $\mathrm{t}(162)$ & $\mathrm{p}$-level \\
\hline const & 3.78241 & 1.298366 & 2.91321 & 0.004083 \\
GTA & -0.39013 & 0.256103 & -1.52334 & 0.129624 \\
NFATA & 0.03829 & 0.495423 & 0.07728 & 0.938497 \\
ROA & 4.19059 & 1.811074 & 2.31387 & 0.021931 \\
IPA & -0.20862 & 0.408015 & -0.51132 & 0.609826 \\
CL & -0.05992 & 0.040280 & -1.48756 & 0.138812 \\
FR & -2.60885 & 1.596397 & -1.63421 & 0.104156 \\
\hline
\end{tabular}

\begin{tabular}{ll}
\hline Multiple R & 0.92353052 \\
R2 & 0.85290863 \\
Adjusted R2 & 0.8746080 \\
F $(6,386)$ & 156.5594 \\
Standard error of estimate & 3.252908977 \\
Durbin-Watson d & 1.367846 \\
Serial Corr. & 0.313927 \\
\hline
\end{tabular}

Source: Authoring

Table 8: Model 2: Pooled Least square method (LSM) 
Full sample 2011-2017

\begin{tabular}{lllll}
\hline & Beta & Std.Err. & $\mathrm{t}(384)$ & $\mathrm{p}$-level \\
\hline const & 2.21591 & 0.753758 & 2.93981 & 0.003483 \\
GTA & -0.53347 & 0.214206 & -2.49045 & 0.013180 \\
NFATA & 0.45218 & 0.262277 & 1.72407 & 0.085499 \\
ROA & 2.78375 & 0.910303 & 3.05805 & 0.002384 \\
IPA & -0.25261 & 0.235443 & -1.07292 & 0.283982 \\
CL & -0.02479 & 0.028253 & -0.87742 & 0.380806 \\
FR & -1.58856 & 0.889038 & -1.78683 & 0.074753 \\
GDPG & 0.05136 & 0.076831 & 0.66843 & 0.504262 \\
INFL & 0.08648 & 0.056075 & 1.54219 & 0.123850 \\
\hline
\end{tabular}

\begin{tabular}{ll}
\hline Multiple R & 0.86045444 \\
R2 & 0.74038184 \\
Adjusted R2 & 0.73497313 \\
F $(6,386)$ & 136.8869 \\
Standard error of estimate & 3.035911215 \\
Durbin-Watson d & 1.122557 \\
Serial Corr. & 0.438324 \\
\hline
\end{tabular}

Pre-crisis 2011-2013

\begin{tabular}{lllll}
\hline & Beta & Std.Err. & $\mathrm{t}(160)$ & $\mathrm{p}$-level \\
\hline const & -18.3781 & 6.645233 & -2.76561 & 0.006350 \\
GTA & -0.7630 & 0.459439 & -1.66072 & 0.098728 \\
NFATA & 0.4239 & 0.345130 & 1.22817 & 0.221188 \\
ROA & 2.8034 & 1.278893 & 2.19203 & 0.029822 \\
IPA & -0.9756 & 0.310179 & -3.14529 & 0.001979 \\
CL & 0.0564 & 0.055287 & 1.02049 & 0.309036 \\
FR & -4.1540 & 1.385428 & -2.99837 & 0.003148 \\
GDPG & 0.1258 & 0.190812 & 0.65905 & 0.510814 \\
INFL & 3.6634 & 1.081069 & 3.38866 & 0.000884 \\
\hline
\end{tabular}

\begin{tabular}{ll}
\hline Multiple R & 0.94752626 \\
R2 & 0.89780601 \\
Adjusted R2 & 0.89269631 \\
F $(6,386)$ & 175.7062 \\
Standard error of estimate & 2.677471023 \\
Durbin-Watson d & 1.102595 \\
Serial Corr. & 0.448672 \\
\hline
\end{tabular}

Post-crisis 2015-2017 


\begin{tabular}{lllll}
\hline & Beta & Std.Err. & $\mathrm{t}(160)$ & $\mathrm{p}$-level \\
\hline const & 2.59076 & 1.515763 & 1.70921 & 0.089350 \\
GTA & -0.36317 & 0.257113 & -1.41249 & 0.159749 \\
NFATA & -0.14941 & 0.513056 & -0.29121 & 0.771270 \\
ROA & 4.16440 & 1.809343 & 2.30161 & 0.022647 \\
IPA & -0.24121 & 0.408504 & -0.59048 & 0.555704 \\
CL & -0.05747 & 0.040292 & -1.42624 & 0.155746 \\
FR & -3.55110 & 1.751482 & -2.02748 & 0.044273 \\
GDPG & 0.76037 & 0.602127 & 1.26281 & 0.208496 \\
INFL & 0.41087 & 0.291664 & 1.40871 & 0.160861 \\
\hline
\end{tabular}

\begin{tabular}{ll}
\hline Multiple R & 0.92467988 \\
R2 & 0.85503289 \\
Adjusted R2 & 0.84778453 \\
F $(6,386)$ & 117.9623 \\
Standard error of estimate & 3.249455337 \\
Durbin-Watson d & 1.384090 \\
Serial Corr. & 0.305821 \\
\hline
\end{tabular}

Source: Authoring

Table 9: Model 3: Pooled Least square method (LSM)

Full sample 2011-2017

\begin{tabular}{lllll}
\hline & Beta & Std.Err. & $\mathrm{t}(385)$ & $\mathrm{p}$-level \\
\hline const & 4.13070 & 1.164131 & 3.54831 & 0.000436 \\
GTA & -0.54992 & 0.213389 & -2.57706 & 0.010336 \\
NFATA & 0.46224 & 0.261328 & 1.76880 & 0.077719 \\
ROA & 2.80794 & 0.907303 & 3.09482 & 0.002113 \\
IPA & -0.28829 & 0.234385 & -1.23001 & 0.219445 \\
CL & -0.02734 & 0.027987 & -0.97696 & 0.329201 \\
FR & -1.41454 & 0.868948 & -1.62788 & 0.104368 \\
SMC & -0.03476 & 0.024353 & -1.42728 & 0.154310 \\
\hline
\end{tabular}

\begin{tabular}{ll}
\hline Multiple R & 0.86029512 \\
R2 & 0.74010770 \\
Adjusted R2 & 0.73538238 \\
F $(6,386)$ & 156.6261 \\
Standard error of estimate & 3.033566314 \\
Durbin-Watson d & 1.122604 \\
Serial Corr. & 0.438359 \\
\hline
\end{tabular}

Pre-crisis 2011-2013 


\begin{tabular}{lllll}
\hline & Beta & Std.Err. & $\mathrm{t}(161)$ & $\mathrm{p}$-level \\
\hline const & 4.86084 & 1.632137 & 2.97820 & 0.003348 \\
GTA & -0.88524 & 0.470705 & -1.88067 & 0.061823 \\
NFATA & 0.72061 & 0.343875 & 2.09556 & 0.037685 \\
ROA & 4.07282 & 1.240851 & 3.28228 & 0.001263 \\
IPA & -0.77580 & 0.314950 & -2.46324 & 0.014821 \\
CL & 0.07563 & 0.056691 & 1.33408 & 0.184060 \\
FR & -2.22174 & 1.297928 & -1.71176 & 0.088866 \\
SMC & -0.03667 & 0.032552 & -1.12663 & 0.261574 \\
\hline
\end{tabular}

\begin{tabular}{ll}
\hline Multiple R & 0.94366538 \\
R2 & 0.89050434 \\
Adjusted R2 & 0.88574366 \\
F $(6,386)$ & 187.0540 \\
Standard error of estimate & 2.762851907 \\
Durbin-Watson d & 1.013260 \\
Serial Corr. & 0.493345 \\
\hline
\end{tabular}

Post-crisis 2015-2017

\begin{tabular}{lllll}
\hline & Beta & Std.Err. & $\mathrm{t}(161)$ & $\mathrm{p}$-level \\
\hline const & 5.72124 & 3.095254 & 1.84839 & 0.066380 \\
GTA & -0.38092 & 0.256865 & -1.48297 & 0.140038 \\
NFATA & 0.00752 & 0.498223 & 0.01510 & 0.987973 \\
ROA & 4.31112 & 1.822393 & 2.36564 & 0.019189 \\
IPA & -0.19005 & 0.409561 & -0.46403 & 0.643251 \\
CL & -0.06072 & 0.040362 & -1.50439 & 0.134441 \\
FR & -2.69713 & 1.604090 & -1.68141 & 0.094622 \\
SMC & -0.04764 & 0.069023 & -0.69027 & 0.491019 \\
\hline
\end{tabular}

\begin{tabular}{ll}
\hline Multiple R & 0.92376547 \\
R2 & 0.85334265 \\
Adjusted R2 & 0.84696624 \\
F $(6,386)$ & 133.8281 \\
Standard error of estimate & 3.258177901 \\
Durbin-Watson d & 1.365065 \\
Serial Corr. & 0.315331 \\
\hline
\end{tabular}

Source: Authoring

Table 10: Model 4: Pooled Least square method (LSM)

Full sample 2011-2017 


\begin{tabular}{lllll}
\hline & Beta & Std.Err. & $\mathrm{t}(383)$ & $\mathrm{p}$-level \\
\hline const & 3.36416 & 1.533761 & 2.19341 & 0.028879 \\
GTA & -0.54321 & 0.214579 & -2.53153 & 0.011756 \\
NFATA & 0.44213 & 0.262626 & 1.68350 & 0.093093 \\
ROA & 2.84035 & 0.912990 & 3.11105 & 0.002004 \\
IPA & -0.26461 & 0.235937 & -1.12155 & 0.262758 \\
CL & -0.02483 & 0.028262 & -0.87864 & 0.380146 \\
FR & -1.58386 & 0.889357 & -1.78091 & 0.075720 \\
GDPG & 0.05916 & 0.077392 & 0.76445 & 0.445071 \\
INFL & -0.06318 & 0.062300 & 1.01407 & 0.311192 \\
SMC & -0.02532 & 0.029447 & -0.85971 & 0.390485 \\
\hline
\end{tabular}

\begin{tabular}{ll}
\hline Multiple R & 0.86074496 \\
R2 & 0.74088189 \\
Adjusted R2 & 0.73479295 \\
F $(6,386)$ & 121.6767 \\
Standard error of estimate & 3.036943054 \\
Durbin-Watson d & 1.125324 \\
Serial Corr. & 0.436948 \\
\hline
\end{tabular}

Pre-crisis 2011-2013

\begin{tabular}{|c|c|c|c|c|}
\hline & Beta & Std.Err. & $\mathrm{t}(159)$ & p-level \\
\hline const & -152.709 & 17.25579 & -8.84970 & 0.000000 \\
\hline GTA & -0.556 & 0.38681 & -1.43819 & 0.152346 \\
\hline NFATA & -0.530 & 0.31226 & -1.69624 & 0.091798 \\
\hline ROA & -1.726 & 1.20726 & -1.42942 & 0.154846 \\
\hline IPA & -1.248 & 0.26269 & -4.75235 & 0.000004 \\
\hline CL & -0.029 & 0.04759 & -0.60842 & 0.543780 \\
\hline FR & -13.086 & 1.59171 & -8.22159 & 0.000000 \\
\hline GDPG & -2.448 & 0.35147 & -6.96375 & 0.000000 \\
\hline INFL & 21.183 & 2.31503 & 9.14999 & 0.000000 \\
\hline SMC & 0.952 & 0.11576 & 8.22715 & 0.000000 \\
\hline
\end{tabular}

\begin{tabular}{ll}
\hline Multiple R & 0.96349367 \\
R2 & 0.92832004 \\
Adjusted R2 & 0.92426269 \\
F $(6,386)$ & 228.7993 \\
Standard error of estimate & 2.249429579 \\
Durbin-Watson d & 1.057756 \\
Serial Corr. & 0.470982 \\
\hline
\end{tabular}

Post-crisis 2015-2017 


\begin{tabular}{lllll}
\hline & Beta & Std.Err. & $\mathrm{t}(159)$ & $\mathrm{p}$-level \\
\hline const & -72.2164 & 17.38300 & -4.15443 & 0.000053 \\
GTA & -0.2300 & 0.24595 & -0.93503 & 0.351191 \\
NFATA & -1.5626 & 0.58667 & -2.66358 & 0.008527 \\
ROA & 0.0810 & 1.96027 & 0.04133 & 0.967082 \\
IPA & -1.1950 & 0.44619 & -2.67824 & 0.008179 \\
CL & -0.0040 & 0.04019 & -0.10025 & 0.920275 \\
FR & -12.3947 & 2.63762 & -4.69920 & 0.000006 \\
GDPG & 9.9779 & 2.20969 & 4.51549 & 0.000012 \\
INFL & 5.5896 & 1.23078 & 4.54149 & 0.000011 \\
SMC & 1.4529 & 0.33646 & 4.31828 & 0.000028 \\
\hline
\end{tabular}

\begin{tabular}{ll}
\hline Multiple R & 0.93287190 \\
R2 & 0.87024999 \\
Adjusted R2 & 0.86290565 \\
F $(6,386)$ & 118.4926 \\
Standard error of estimate & 3.083833725 \\
Durbin-Watson d & 1.465702 \\
Serial Corr. & 0.265184 \\
\hline
\end{tabular}

Source: Authoring 